ducts, with their columnar epithelium unchanged, multiplied 100 diameters. The lower figure represents a part of the new growth shewing a mass of cells and nuclei of elongated form, constituting a cord-like body, like those seen under the skin, multiplied Iooo diameters; and a part of the new growth multiplied 1000 diameters, shewing cells imbedded in a trabecular work of fibres.

FIG. 6.- A small nodule from the omentum of the guinea-pig, seated at the bifurcation of a small artery. In the denser part around the artery little is to be seen but a closely packed mass of nuclei. The nuclei lie imbedded in the broad bands of fibrillated tissue, of which the



Fig. 6

omentum is composed. Even in the denser parts a reticular arrangement of the growth is thus preserved, but the open spaces are diminished in size. At a greater distance, the growth is still seen to originate from the same nuclei, which lie in rows imbedded in the fibres. In some places, an outer cell-wall around the nuclei is visible, the cells being large and round. Multiplied rooo diameters.

ERRATUm. In last number of Journal, May 30, p. 526, second column, sixth line, instead of "what is ordinarily considered not tubercle," read "what is ordinarily considered to be tubercle."

Alcohol in the Treatment of Pnecironia.-M. Pécholier, in a work lately published by him on this subject, expresses his opinion as follows: "We hold it to be demonstrated, by facts and arguments, that the beneficial action of alcohol in certain kinds of inflammation, and specially in certain kinds of pneumonia, is, in the first instance, due to the stimulating action of this agent. We, therefore, accept a portion of Todd's theories, without falling into his exclusiveness. If, in all cases of pneumonia, the vital powers are not always greatly weakened, as the English physician asserts, there exists a kind of pneumonia in which the radical forces are destroyed, and in which curative reaction requires to be stimulated. For this kind of pneumonia, Dr. Todd's prescription is proper; in others, it is useless, and sometimes even injurious."

\section{CONTRIBUTIONS TO THE HISTORY OF MEDICINE.}

By AQUILLA SMITH, M.D.,

Professor of Materia Medica and Pharmacy in Trinity College, Dublin.

I.-ON the Treatment of Coryza, or NASAl Catarrh, by "A TOTAL ABStinenCE From LiQUid."

Dr. Charles J. B. Williams, in the article "Coryza" published in the Cyclonadia of Practical Medicine in 1833, after giving the usual treatment by aperients, diaphoretics, and diluents, adds: "It is the acrimony of this discharge (from the pituitary membrane) which reacts on the membrane and keeps up the inflammation and its accompanying disagreeable symptoms. On this circumstance depends the efficacy of a measure directly opposed to that just noticed, but to the success of which we can bear decided testimony-we mean a total abstinence from liquids." "This method of cure operates by diminishing the mass of fluid in the body to such a degree that it will no longer supply the diseased secretion." "The coryza begins to be dried $\iota p$ about twelve hours after leaving off liquids; from that time the flowing to the eyes and fulness in the head become less and less troublesome; the secretion becomes gelatinous, and between the thirtieth and thirty-sixth hour ceases altogether. The whole period of abstinence needs scarcely ever to exceed forty-eight hours."

Assuming that priority of publication of opinions or experiments is justly entitled to the merit of originality, and without any intention of detracting from Dr. Williams's acknowledged reputation, I proceed to show that, in his method of treating coryza, he was anticipated by an eminent English physician at the close of the seventeenth century.

The author, in Tractatus de Corde, cui accessit Dissertatio de Origine Catarrhi, in qua ostenditur illum non provenire a Cerehro, authori Richardo Lower, M.D., editio tertia et ultima, Amstelodami I67I, in cap. vi, De Catarrhis, says: "Cùm vero catarrhi materia, occasio atque organcrum in eo secernendo ministeria ex præmissis constiterint; satis obvium et facile erit concipere quod illi sistendo aptissimè conferet..... In quantum igitur ex sero sanguinis materia catarrho suppeditatur, quicquid ei pabulum detrahit, aut serum per renes præcipiat, vel per alvum derivat, vel per poros corporis dispellit, intentioni curativæ apprimè satisfacit. Quare quum catarrhus primo urget, nihil majus ei supprimendo conducit, modo absque febre sit, quam ut sitim diutissimè toleremus; tridui enim vel quatridui abstinentia d potu plures novi à catarrho prorsus liberatos, cujus alia ratio non est, quàm quod fomite subducto orinino exsiccatur, non aliter ac rivuli exarescunt ex pluviarum penuriâ." (P. 234.)

In the extracts from Dr. Williams's article on Coryza, the words in italics are his own; and in the quotation from Lower $I$ have put a few words in italics to shew the parallelism.

\section{ON IODIDE OF METHYLE AND THERAPEUTICAL RESEARCHES.}

\section{By JAMES TURNBULL, M.D., Liverpool.}

I OBSERVE in the BRITISH MEDICAL JoURNal of April r8th, a report of a meeting of the Medical Society of London, at which Dr. B. W. Richardson presided and exhibited a specimen of iodide of methyle, which, he thought, promised to prove of the greatest use in practical medicine. He also made the statement that the iodide was first experimented with physiologically by himself last year, and was reported on by him to the meeting of the British Association at Dundee. It is proper that I should correct this statement and the error into which Dr. Richardson has unwittingly fallen ;* for if there be any merit in being the first to investigate the physiological properties of this and other allied compounds, I ought to assert my claim to it, having read a paper, at the meeting of the British Association for the Advancement of Science held at Liverpool in I854, entitled "Researches on the Physiological and Medicinal Properties of some of the compounds of the Organic RadicalsMethyle, Ethyle, and Amyle." The paper was afterwards published in the Association Medical Journal, where, in the volume for I865, page 69 , the following account of the properties of iodide of methyle is given.

" Iodide of Methyle. - The next compound of methyle, the iodide, is a

* April 22nd, r868. Since this was written and sent to the Editor of the JourNal, Dr. Richardson has in the most handsome manner rectified this mistake by a statement made at tbo subsequent meeting of the Medical Society of London. - J. T. 
more important one. It is a transparent, oily-looking liquid, which dissolves very sparingly in water, and is exceedingly heavy, its specific gravity being 2,257 . It is very volatile, and the vapour is rather pungent. In odour and taste it is more pleasant than wood-spirit, to which it bears some resemblance. Like other ethers, it acts as a diffusible stimulant, but is more powerful than most of them. 'The immediate heating and exciting effect it produces upon the system is undoubtedly due to the methyle base, but it also produces the physiological effects of iodine, and this we should naturally expect when we consider that iodine constitutes nine-tenths of the weight of the compound. It increases the secretions, especially the salivary and urinary, and it affects the mouth, the gums becoming red and swollen, with a tendency in some instances to bleed. In half an hour after a few drops have been swallowed, the presence of iodine may be detected in the saliva and in the urine by means of the starch and sulphuric acid test; and, as the iodide of methyle itself does not act with this test, it is evident that it must be rapidly decomposed in the animal economy, the methyle being separated from the iodine, which no doubt unites with sodium or potassium. I have prescribed it as an internal remedy in some cases where it was desirable to give iodine as a medicine; but, as its stimulating effects are sometimes objectionable, I have directed my attention more to its use as an external remedy, and $\mathrm{I}$ have also used it for inhalation. Iodide of methyle unites readily with lard, and in the proportion of half a drachm or a drachm to the ounce it forms a stimulating ointment, which I have tried with advantage as an application to indolent ulcers, more especially those of scrofulous nature. I have also used it in two cases of psoriasis, one of them of syphilitic origin, and in both it assisted, in conjunction with the internal means which were likewise employed, in removing the scaly eruption of the skin. In directing my attention to these ethereal compounds, I was influenced in some measure by a desire to obtain remedies capable by their volatility of being made to act directly upon ulcers of the lungs. I formerly stated, in my report on the 'Progress of Improvement in the Treatment of Consumption,' that we often succeed in arresting this disease without being able to heal the ulcers which have formed in the lungs; that the disease is in consequence apt to regain new activity, and that I considered the discovery of means which would promote the cicatrisation of cavities in these cases of arrested phthisis a desideratum, and a legitimate object of inquiry. Having, therefore, found iodide of methyle useful as an application to external ulcers, I was naturally led to expect that it might prove serviceable when applied to those of the lungs in the way of inhalation. I have used it in cases such as I have alluded to, and in some I think it has been of service. It is, however, too pungent when there is any considerable bronchial irritation; and where this is the case, I have found another compound, which I shall presently describe, more applicable, viz., the iodide of ethyle."

I have long thought, and on more than one occasion I have expressed the opinion that, therapeutical inquiry has been the most neglected branch of scientific medicine. Pathology, which shows us more of the effects of disease than of the way to treat it, has been much cultivated, and we have made sufficient advances in this branch, and also in our knowledge of the natural history and course of diseases, so that we are no longer without a good basis for scientific therapeutical inquiry. Meanwhile organic chemistry has been making great strides, opening a way for those who have opportunity and ability to enter experimentally into this promising field; and I am glad to see that the profession has become alive to the importance of the subject. I have read with much satisfaction the account in this Journal of Drs. Crum Brown and $T$. R. Fraser's interesting researches into the relation existing between the chemical constitution and the physiological action of medicinal and poisonous substances, and on the addition of iodide of methyle to vegetable alkaloids ; likewise the forcible paper "On Drugs," which was brought by Dr. Fuller before the Harveian Society; and I rejoice to see that so scientific an observer as Dr. Richardson is bending his attention in a similar direction.

Many of the simplest and most practical therapeutical questions may be said to have received little or no scientific examination. By way of illustration, I may observe, in regard to iodine, that it must vary in its effects according to the base with which it is combined. Iodide of iron, for example, does not seem to have any greater efficacy in the treatment of secondary syphilis than other preparations of iron-certainly not the efficacy of iodide of potassium; therefore we know that the action of iodine must be materially affected by the base with which it is combined. Well directed scientific inquiry should, with the aid of chemistry, throw light on a difference of effect such as this. And it might be a fit subject for the Therapentical Committee of the Harveian Society to propose for investigation the modifications in the action' of iodine from its combination with potassium, sodium, ammonium, and other bases.

In the form of iodide of potassium, it is believed that in most individuals it is eliminated chiefly by the kidneys. My researches showed me two singular facts in regard to its action when in combination with methyle and ethyle, which seem to prove that its action may be diverted from one to another organ by the base with which it is combined. Whether inhaled or given internally, iodide of methyle quickly affects the mouth, and even causes the gums to bleed; and iodide of ethyle produces a similar but less quick and energetic action on the mouth. Observing these facts, I thought I had discovered compounds of iodine which would prove of superior efficacy in the treatment of syphilis; but on trial, I found them very inferior to iodide of potassium, and I am even doubtful if iodide of ethyle, which I tried in many cases, has any value in this disease.

I may advert to another interesting fact in regard to iodide of ethyle. We all know that, when sulphuric ether-that is, oxide of ethyle-is taken medicinally, it is largely eliminated by the lungs, the breath being strongly impregnated with its odour. When iodine is combined with the ethyle base, and the iodide of ethyle is either given internally or by inhalation, the breath soon acquires a peculiar garlic-like odour, no such effect being produced by iodide of methyle. From these facts I would infer that, the combination of iodine with one base may direct its action to one organ in particular, and with another base to a different organ. Does the combination of iodine with methyle direct the action more particularly to the mouth and gums? the combination with ethyle to the lungs? with potassium to the kidneys? with sodium to the liver? with ammonium to the skin? These, or some of these, are questions on which medical men engaged in the daily business of practice must form opinions from general observation, but they cannot solve them without such experimental researches, aided by chemistry, as they have not the time and opportunity to engage in. Let us, however, hope that the attention now directed to therapeutical investigations will lead to the collection of more definite facts relating to such simple questions, so that we may have not only new remedies, but also more exact knowledge of those we wield in our warfare with disease.

\section{NOTES ON THE PATHOLOGY OF ARABIAN ELEPHANTIASIS}

By JOHN COCKLE, A.M., M.D., Physician to the Royal Free Hospital, etc.

A VERY moderate acquaintance with the subject shows us that there are at least three points in the history of Arabian elephantiasis sufficiently interesting to merit attention:- -first, that a disease possessing such trenchant characters, and one moreover, though endemic, and at times epidemic in some countries, nevertheless common to all, should (unless of later origin) have escaped the notice both of the Greek and Latin observers; second, that, although so admirably described about the ninth century, in its two more commonly observed forms, by Rhazes (nearly the only really original physician who flourished during an almost Augustan period of the Arabian Caliphate), the disease in question was but dimly recognised during succeeding ages until our own countrymen, in the eighteenth century, described, with accuracy of detail, its more general characters and affinities, as observed among the inhabitants of the island of Barbadoes. For, although Prosper Alpinus, in the sixteenth century in Egypt, Kæmpfer, on the coast of Malabar, and the physicians of the French army in Egypt, in the eighteenth century, had partially discerned the features of the disease, still the then current terms, "fleshy hernia" (Alpinus), " endemic hydrocele," "pedarthrocasis" (Kæmpfer), and "sarcocele" (Larrey), applied to the same elementary lesion, sufficiently prove how crude were the notions held by them as to its true pathology. The third point is the uncertainty which even yet exists respecting the precise ætiology of the affection, which has been handed down to us under the designation of elephantiasis Arabûm-the suffix, as is well known, being intended not to indicate a country to which it is peculiar, but to honour the people who first so well described it.

Arabian elephantiasis must now be regarded as a generic name under which many affections have been included; some, clearly on inadequate pathological grounds, while others, with a more direct affinity, have been excluded. All, however, mostly present an unnatural and more or less abiding deformity of the part affected, caused by actual augment or degeneration of the tissues involved.

Affections, the most dissimilar, may operate as the exciting causes of elephantiasis. Some of the earlier English pathologists alluded to were disposed to adopt a humoral origin of the disease; but one, Dr. Hendy, as also a French physician, Dr. Alard (possibly influenced by recent interesting researches respecting the absorbent system) regarded inflammation of these vessels as the proximate local cause of the affection, and 